\title{
The Effects Of Shariah Supervisory Board Education Qualifications, Number Of Shariah Supervisory Board Meetings And Management Bonus Compensation On Earnings Management
}

\author{
Iwan Fakhruddin ${ }^{1}$, Edi Joko Setyadi², Hadi Pramono ${ }^{3}$ \\ \{iwanfakhruddin@ump.ac.id ${ }^{1}$, edijokosetyadi@ump.ac.id ${ }^{2}$,pramono.hadi.75@gmail.com ${ }^{3}$ \} \\ Universitas Muhammadiyah Purwokerto ${ }^{1}$, Universitas Muhammadiyah Purwokerto ${ }^{2}$, Universitas \\ Muhammadiyah Purwokerto ${ }^{3}$
}

\begin{abstract}
The purpose of this research study is to examine the effect of Shariah Supervisory Board Education Qualifications, Number of Shariah Supervisory Board Meetings, and Management Bonus Compensation on Earnings Management Practices. The population used is the Shariah Commercial Bank registered at Bank Indonesia in 2014-2018. The secondary data collection technique is done by searching the annual report data issued by each Islamic commercial bank. Multiple regression analysis is used to test the effect of Shariah Supervisory Board Background, Number of Shariah Supervisory Board Meetings, and Management Bonus Compensation on Earnings Management Practices. Research Results Show that the Educational Qualification and Number of Meetings of the Shariah Supervisory Board do not affect earnings management practices. Whereas Management Bonus Compensation has a positive effect on earnings management practices. This shows that the characteristics of the Shariah Supervisory Board do not cause earnings management practices in Islamic financial institutions to occur or not occur. However, bonus compensation received by managers causes managers to be motivated to do earnings management. Earnings management practices by management are shown through positive or negative Discretionary Accrual values.
\end{abstract}

Keywords: Shariah Supervisory Board, Bonus Compensation, Earning Management

\section{Introduction}

In accounting, known as earnings reporting practices such as income smoothing, earnings management, and other substances. This practice can be done because the manager has more information about the business than the owner. This causes changes in information. Besides, there is also a moral impulse of danger from agents to be carried out in the interest of onesided. The Agency Theory discovered by [1] sees contracts between shareholders and managers as an agency relationship (agency relationship). Ownership of shares in the principle that authorizes managers as agents to manage the company on behalf of shareholders. Managers assume satisfaction in the form of money (benefits of money) and satisfaction in the form of non-financial (non-financial benefits), non-financial satisfaction is non-productive nature, then the activity will increase the value of the company and provide only in this case the shares that are disadvantaged. This incident will cause conflicts between managers and company owners. 
Earnings management or earnings management is one form of agency problems. Earnings management occurs because of information asymmetry between the manager as an agent and the owner of the company as a principal. In this case, the manager has deeper information about the company compared to its owner. This information gap often encourages opportunistic behavior (opportunistic behavior) of managers to maximize profits on themselves. One form of this opportunistic policy is done with financial reporting with fraudulent financial reporting. Earnings management practices give rise to financial statements which provide a bias for investors and have an impact on financial finance.

The fraudulent presentation of the report is intended by the performer to benefit the manager's interests. For example, the manager wants to be assessed by the owner's good performance, so he will get a bonus from the performance. Earnings management is interference in the external financial reporting process with a view to self-benefit. Earnings management is one of the factors that can reduce the credibility of financial statements, earnings management adds a bias in the financial statements and can interfere with users of financial statements that trust the engineered profit figures as non-engineered profit figures. Earnings management is done by playing with the accrual components in the financial statements because accruals are an easy component to be mocked by the wishes of the person who records transactions and prepares financial statements [2] In earnings reporting, earnings management is not always associated with efforts to manipulate accounting data or information but rather is associated with the choice of accounting methods that are deliberately chosen by management for certain purposes within GAAP limits.

Those who are contra to earnings management assume that earnings management is a reduction in the reliability of the information that is accurate enough about earnings to evaluate the return and risk of its portfolio. Earnings management actions have led to several cases of accounting reporting scandals that are widely known, including cases that occurred in Indonesia, which are listed in Bapepam-LK, some cases have received enough public attention.

This study purpose to analyze the influence of SSB Qualification, SSB meetings, and management bonus compensation on earnings management practice. This study was conducted in Islamic banking which has characteristics and is different from conventional banking. Following Law No. 21 of 2008 concerning Islamic banking, Islamic banks are banks that carry out their business activities based on shariah principles (Shariah compliance), so that Islamic banks are not only regulated by banking laws but also Islamic principles relating to religion. When associated with earnings management practices, true earnings management does not occur in Islamic banking because of the Islamic principles inherent in this bank. Besides, there is a dual banking system policy in the conventional banking industry following Law No. 21 of 2008, where conventional banks may open a shariah business unit which is the forerunner to the establishment of shariah commercial banks in general, so earnings management practices can occur in Islamic banks because, in several studies conducted at conventional banks, the bank is proven to have carried out management practices profit. Some research on earnings management practices has been conducted at Islamic banks. According to [3], Islamic banks must have a shariah advisory board with good knowledge in finance to help bank management develop new products by shariah principles. [4] also found evidence of the number of meetings and the background of the Shariah Supervisory Board did not affect earnings quality (earnings management practices). 


\section{Literature Review}

\subsection{Agency Theory}

Agency theory (agency theory) is a condition that occurs in a company where management is the executor referred to as the agent and owner of capital as the principal of building a cooperation contract called "nexus of contract"[1]. This collaboration contains agreements that explain the parties' company management must work optimally to provide maximum satisfaction such as high profit to the capital owner (owner). Principal as the owner of the company is obliged to provide facilities and funds for the company's operating needs, while the agent as a company manager is obliged to manage a company that entrusted by the shareholders to him, to prosper and shareholder profits, through increasing company value. Therefore the agent, in this case, the company manager, will get a salary and bonuses and various other compensation. In situations like this, you can the occurrence of opportunistic behavior (opportunistic behavior) by managers who appointed to carry out the company's operations are not run with good, or act only for personal gain.

Earnings management is an intervention by managers in the process of preparing financial statements for external parties so that they can flatten, increase, and decrease earnings reporting, which is management can use the leeway of using accounting methods, make policies (discretionary) that can accelerate or delay costs and revenues so that the company's profits are smaller or larger as expected. Actions of earnings management are based on various goals and purposes of certain motivations. This happens because the level of profit or profit obtained is often associated with management achievements. The size of bonuses and benefits that will be received by managers, one of which is influenced by the size of the profits obtained [5]

\subsection{Shariah Supervisory Board (SSB)}

Shariah Supervisory Board is a body that is given the authority to supervise/supervise and closely look at the activities of shariah financial institutions so that these institutions always follow the rules and principles of shariah [6]. SSB sees in broad terms the aspects of management and administration that must be following shariah, and most importantly, endorsing and supervising shariah banking products to comply with shariah provisions and applicable laws. One of the fundamental differences in the organizational structure of conventional banks and Islamic banks is the obligation to position the Shariah Supervisory Board in Islamic banking while in conventional banks there is no such regulation. The Shariah Supervisory Board is a council of economic experts and scholars who master the fiqh mu'amalah (Islamic commercial jurisprudence) which stands alone and is tasked with observing and overseeing the operations of the bank and all of its products to be following the provisions of Islamic Shariah. The Shariah Supervisory Board must look closely at the forms of agreements (agreements, appointments, and engagements) carried out by Islamic financial institutions.

In the Decree of the Directors of Bank Indonesia paragraphs 2 and 3 of article 19 dated May 12, 1999, it was stated that: Banks are required to have a Shariah Supervisory Board domiciled at the head office of the bank. Requirements as a member of the Shariah Supervisory Board are regulated and determined by the National Shariah Board. In Indonesia, the Shariah Supervisory Board has a very important role in shariah banking / financial institutions, namely: 
1. Making approval of the operational guidelines for shariah banking products following the provisions that have been prepared by the National Shariah Board.

2. Make periodic statements every year about shariah banks that are under their supervision that the bank under their supervision has been running following shariah provisions. In an annual institutional report, the report from the Shariah Supervisory Board must be made clear.

3. The Shariah Supervisory Board is required to make a report on the development and application of the Islamic financial system in Islamic financial institutions, especially the Islamic bank which are under its supervision, at least six months.

4. The Shariah Supervisory Board is also obliged to examine and make recommendations if there are innovations of new products from the bank under its supervision.

5. It is this Council that conducts a preliminary review before the new product from the Islamic bank is proposed, re-examined, and is registered by the National Shariah Board.

6. Helping the socialization of banking / Islamic financial institutions to the public.

7. Provide input (input) for the development and progress of Islamic financial institutions.

Shariah supervisory boards in the organizational structure of shariah banks are placed in one level with the Board of Commissioners of each shariah bank. Such a position aims to make the Shariah Supervisory Board more authoritative and have freedom of opinion in providing guidance and direction to all directors in banks in cases relating to the application of Islamic banking products. One important thing to analyze is the importance of the Shariah Supervisory Board to earnings management practices in Islamic financial institutions. Previous research shows the quality of the shariah supervisory board is related to earnings management and is effective in monitoring activities [7] The Shariah Supervisory Board also influences the company's financial performance [8].

\subsection{Bonus Compensation}

Bonus compensation is all income in the form of money, direct or indirect goods received by the manager as a gift or service provided to the company. Compensation programs are policies and procedures for providing compensation to management, including the awarding of bonuses based on achieving performance goals for a period. If the company has compensation (bonus schemes), then managers will tend to take actions that regulate net income to be able to maximize the bonuses they receive. Benefits of earnings management behavior include achieving their compensation contracts, managing capital adequacy, smoothing profits, checking stock price behavior, and signifying personal information to outside investors [9]. Shariah plays an important role in shaping the ethical behavior of shariah bank managers. Religiosity literature implies that religiosity is positively related to risk avoidance and negatively associated with unethical behavior [10].

\section{Method}

The population in this study are financial institutions that operate following Shariah principles in Indonesian Islam banking. The sample of this study is an Islamic financial 
institution registered with the Central Bank of Indonesia. Data obtained through the website of the Central Bank of Indonesia (www.bi.co.id) and the websites sample of the companies. The sampling technique used is Saturated Sampling. Saturated Sampling Technique is a sample Determination technique that makes all members of a population sample. The sample is 13 Islamic finance institutions in Indonesia. The fiscal year 2014 - 2018 was chosen for this study because most banks have uploaded their annual reports on their website. Data also quite new to ensure access through the company's Internet. The data obtained gives a rationalization.

The dependent variable in this study is earnings management. Earnings Management is measured by calculating the level of earnings management using the Discretionary Accrual Jones Models method. The first independent variable is the qualification (education) of the Shariah Supervisory Board. Qualifications are the Background of Doctoral Education in the Shariah Supervisory Board especially in the fields of Economics, Accounting, Shariah Economic Law, Shariah, Fiqh. The next independent variable is the Shariah Supervisory Board Meeting. Shariah Supervisory Board Meeting is the number of Shariah Supervisory Board meetings in 1 year. Another independent variable is the Management Bonus Compensation. Management bonus compensation is compensation which is a policy and procedure for providing compensation to management, including giving bonuses based on achieving performance targets for a period. Management Bonus Compensation is measured in category 1 for financial institutions that provide bonus compensation and 0 for financial institutions that do not provide bonus compensation.

\section{Result And Discussions}

\section{Findings}

1. Descriptive Statistic

Table 1. Descriptive Statistic

\begin{tabular}{lrrrrrr}
\hline & $\mathrm{N}$ & Minimum & & Maximum & Mean & Std. Deviation \\
\hline Earning_Management & 65 & -.1679 & .1353 & -.023947 & .0602151 \\
SSB_Qualification & 65 & 0 & 3 & 1.51 & .831 \\
SSB_Meetings & 65 & 6 & 30 & 17.63 & 7.361 \\
Valid N (listwise) & 65 & & & & \\
\hline
\end{tabular}

Descriptive analysis results show that earnings management is shown through the calculation of the Accrual Dictionary (DA), which shows that banking companies from 2014 to 2018 did earnings management, both with a pattern of increased profits (increased revenue) and increased profits (decreased revenue). Table 5.2. Shows 2 members of the Shariah supervisory board who have the educational background of S3. Although there is one Islamic financial institution that also shows Islamic financial institutions that do not have Shariah supervisory board members with an S3 education background. The results of the descriptive analysis also provide information on the average shariah supervisory board of shariah financial institutions that have conducted board activities at least 12 times following the 
provisions, discussing several shariah financial institutions that have less than 12 shariah board supervisors.

Tabel 2. Bonus Compensation

\begin{tabular}{cllll}
\hline & Frequency & Percent & Valid Percent & Cumulative Percent \\
\hline Valid 0 & 25 & 38.5 & 38.5 & 38.5 \\
1 & 40 & 61.5 & 61.5 & 100.0 \\
Total & 65 & 100.0 & 100.0 & \\
\hline
\end{tabular}

Bonus compensation is the company's policy to provide bonus compensation to management or not. Measurements were made with Bonus Compensation with dummy variables. Companies that provide bonus compensation to their managers are coded 1 and if they are not coded 0. From table 5.3 above it can be seen that as many as 25 or $38.5 \%$ of Islamic financial institution data does not provide bonus compensation from the total data sample of 65 . While 40 or $61.5 \%$ of data on Islamic financial institutions that provide bonus compensation.

2. Multiple Regression Analysis

Tabel 3. F Model Test

\begin{tabular}{|c|c|c|c|c|c|c|}
\hline \multicolumn{7}{|c|}{ ANOVA $^{a}$} \\
\hline Model & & Sum of Squares & df & Mean Square & $\mathrm{F}$ & Sig. \\
\hline \multirow[t]{3}{*}{1} & Regression & .023 & 3 & .008 & 2.274 & $.089^{\mathrm{b}}$ \\
\hline & Residual & .209 & 61 & .003 & & \\
\hline & Total & .232 & 64 & & & \\
\hline
\end{tabular}

a. Dependent Variable: Earning_Management

b. Predictors: (Constant), Bonus_Compensation, SSB_Meetings, SSB_Qualification

\begin{tabular}{|c|c|c|c|c|c|c|}
\hline \multirow[b]{2}{*}{ Model } & & \multicolumn{2}{|c|}{$\begin{array}{l}\text { Unstandardized } \\
\text { Coefficients }\end{array}$} & $\begin{array}{l}\text { Standardized } \\
\text { Coefficients }\end{array}$ & \multirow[b]{2}{*}{$\mathrm{t}$} & \multirow[b]{2}{*}{ Sig. } \\
\hline & & $\mathrm{B}$ & Std. Error & Beta & & \\
\hline \multirow[t]{4}{*}{1} & (Constant) & -.071 & .028 & & -2.560 & .013 \\
\hline & SSB Qualification & .000 & .010 & .005 & .035 & .972 \\
\hline & $\mathrm{SSB}$ meeting & .002 & .002 & .134 & 1.099 & .276 \\
\hline & Bonus_Compensation & .035 & .017 & .283 & 2.032 & .046 \\
\hline Depenc & t Variable: Earnings Ma & gement & & & & \\
\hline
\end{tabular}

Based on Table 5.9 shows that the Shariah Supervisory Board Qualification variable has a significance value of 0.972. This means that the Shariah Supervisory Board Qualifications do not affect Profit Management. This means that the Shariah Supervisory Board's educational qualifications do not affect Profit Management. The Shariah Supervisory Board's qualifications do not affect earnings management. The presence or absence of a member of the Shariah Supervisory Board is not a reason for management to do or not do earnings management. This is possible because only about $25 \%$ of the Shariah Supervisory Board in Indonesian Islamic financial institutions have doctoral backgrounds in the fields of Islamic Law, economics, and finance and accounting, and only about $10 \%$ of the Shariah Supervisory Board has a doctorate background in economics, finance, and accounting [11]. Some Shariah Supervisory Board members who have doctoral backgrounds in economics, finance, and accounting have caused Shariah Supervisory Board Members to not pay too much attention to the presence or absence of earnings management practices in Islamic financial institutions. 
[12] and [3] obtained the results of research that the Islamic supervisory board can effectively reduce earnings management practices in Islamic banks. A shariah supervisory board consisting of shariah scholars is assigned and oversees the activities of shariah financial institutions to ensure that these institutions adhere to shariah principles. The existence of shariah supervisory boards in Islamic financial institutions as advisors and provide advice to managers who act as managers in every decision making so that decisions taken do not cause conflicts between managers and company owners. Shariah supervisory board as shariah scholars who understand shariah law and principles supervise and provide advice to management in carrying out bank operations following shariah principles. This is because one of the problems with the function of the shariah supervisory board in implementing corporate governance is competence in carrying out its functions. The Shariah Supervisory Board is expected to be familiar with Islamic law and have financial expertise [12].

Based on Table 5.9 shows that the Shariah Supervisory Board Meeting variable has a significance value of 0.276 . These results indicate that the Shariah Supervisory Board Meeting does not affect management whether earnings management practices in Islamic financial institutions or not. The membership of the Shariah Supervisory Board that is connected to the external environment must be able to enable the Shariah Supervisory Board to monitor externally and communicate about possible earnings management practices. The Supervisory Board Meeting must be one medium for sharing information and as a source of information about other activities and policies carried out by managers, especially regarding the presentation of financial statements [6]. However, the results of this study indicate that Shariah Supervisory Board meetings have not been effective in knowing and discussing earnings management practices that may be carried out by managers. According to [13] and [3], shariah supervisory boards must be effective in reducing earnings management practices in Islamic banks But, The results of the study of [11] and [14] find evidence that the number of Shariah Supervisory Councils has a negative influence on earnings management practices

Based on Table 5.9 shows that the Management Bonus Compensation variable has a significance value of 0.046. This means the Management Bonus Compensation affects Earnings Management. Management bonus compensation is the main motivation for managers or other boards of directors in Islamic financial institutions to manage income. Bonus Package (Bonus Scheme) for Managers who work for companies that implement bonus packages will try to manage reported profits to maximize the number of bonuses they will receive [15] and [16]. Other managers or boards of directors who are mandated to manage financial institutions tend to be motivated to maximize the fulfillment of their economic and psychological needs, especially to obtain compensation contracts, compared to behavior that is following Islamic law in carrying out an acceptable mandate. However, this study also assumes that the value of earnings management in Islamic financial institutions will be lower compared to other institutions [9], [17], and [18]. This is because Islamic financial institutions are institutions that carry out operational activities using shariah principles based on the Qur'an and Hadith

\section{Conclusions}

he results showed that the Shariah Supervisory Board Doctoral Education Qualification and the Number of Shariah Supervisory Board Meetings did not affect earnings management practices. Educational qualifications and Shariah Supervisory Board Meetings have not 
effectively become variables and media to detect the presence or absence of earnings management practices in Islamic financial institutions. This is due to the composition of the membership of the Shariah Supervisory Board which has a low doctoral education background in economics, finance, and accounting. The results of this study also show that management bonus compensation motivates managers and other directors to practice earnings management. These findings provide useful insights into earnings management practices particularly among Islamic Financial Institutions in Indonesia. Managers and other directors must realize and understand that the application carrying out the mandate must be accounted for following Islamic law to the owner and Allah Suhanahu Wa Ta'ala.

\section{References}

[1] Jensen. M.C., dan Meckling, W.H. Theory of The Firm: Management Behavior, Agency Cost, and Ownership Structure. Journal of Financial Economics, 3. pp.305-360 (1976)

[2] Sulistyanto, Sri.. Manajemen Laba Teori dan Model Empiris. Jakarta: Grasindo (2018). In Indonesian

[3] Ghayad, R.,. Corporate governance and the global performance of Islamic banks. Humanomics, 24(3), pp.207-216 (2018)

[4] Hendra, Grandis Imama. Analysis of the Effect of Shariah Supervisory Board (SSB) Function on Earning Quality of Islamic Banks. Tazkia Islamic Finance and Business Review Volume $10.2(2018)$

[5] Fahmi, Irham. Manajemen Keuangan Perusahaan Dan Pasar Modal. Jakarta Mitra Wacana Media. (2014). In Indonesian

[6] Fakhruddin, Iwan., \& Jusoh, Mohd. Abdullah. Influence of Shariah Supervisory Board Characteristics on the Shariah Compliance. Advances in Social Science, Education and Humanities Research, 231, 355-357 (2018)

[7] Cornett, M.M., J.J. McNutt, and H. Tehranian. Corporate Governance and Earnings Management at Large U.S. Bank Holding Companies, Journal of Corporate Finance, pp. 412 430 (2009)

[8] Pramono, Hadi and Fakhruddin, Iwan, , Corporate Governance Analysis Of Shariah General Banks In Indonesia, Prosiding Seminar Nasional Hasil Penelitian dan Pengabdian Pada Masyarakat IV Tahun 2019 "Pengembangan Sumberdaya menuju Masyarakat Madani Berkearifan Lokal” LPPM - Universitas Muhammadiyah Purwokerto; 520-526 (2019). In Indonesian

[9] Quttainah, Majdi Anwar; Liang Song and Qiang Wu. "Do Islamic Banks Employ Less Earnings Management?", Journal of International Financial Management \& Accounting, 24: 203-233. (2013)

[10] Dyreng, S.D., W.J. Mayew, and C.D. Williams. Religious Social Norms and Corporate Financial Reporting," Working paper (Duke University (2010).

[11] Fakhruddin, Iwan; Jusoh, Mohd. Abdullah, and Norwani, Norlia Binti Mat. Advances in Business Research International Journal, 6(1) 2020, 20-24 (2020)

[12] Grais, W and Pellegrini M., Corporate Governance and Shariah Compliance in Institutions Offering Islamic Financial Services", World Bank Policy Research Working Paper. (2006)

[13] Mersni, Hounaida, Othman. Hakim Ben. The Impact of Corporate Governance Mechanisms on Earnings Management in Islamic Banks in the Middle East Region. Journal of Islamic Accounting and Business Research, 7(4); 318-348. (2016) 
[14] Saiful, Asrie Dyah. Corporate Governance and Earnings Management: A Study of Indonesian Conventional and Islamic Banks. Advances in Social Science, Education and Humanities Research, volume 292. (2018)

[15] Scott, W. R. Financial Accounting Theory. Edisi Ketiga. Prentice-Hall. (2003)

[16] Luthfi, Hasan Abdur Rohman and Fakhruddin, Iwan. Pengaruh Corporate Governance Terhadap Manajemen Laba Di Industri Perbankan Pada Perusahaan Yang Terdaftar Di BEI. Kompartemen. Vol. XIV; 40-48. In Indonesian. (2016)

[17] Nurianah, What is earning management in shariah lower than the conventional bank?, Journal of Islamic Accounting and Finance Research - Vol. 1 No. 1. (2019)

[18] Hamdi, Faouzi Mohamed, and Zarai, Mohamed Ali. Corporate Governance Practices and Earnings Management in Islamic Banking Institutions. Research Journal of Finance and Accounting, Vol.5, No.9. (2014) 